\title{
Origins of Banks and Credit Supply in Ivory Coast
}

\author{
Prao Yao Seraphin ${ }^{1}$ \\ ${ }^{1}$ Laboratory for economic policy analysis and modelling, University of Bouaké, Bouaké, Ivory Coast \\ Correspondence: Prao Yao Seraphin, Laboratory for economic policy analysis and modelling, University of \\ Bouaké, Bouaké, 01 BP 18 Bouaké 01, Ivory Coast. E-mail: praoseraph@gmail.com
}

Received: March 6, 2020

doi:10.5539/ijef.v12n5p81
Accepted: March 18, 2020

Online Published: April 20, 2020

URL: https://doi.org/10.5539/ijef.v12n5p81

\begin{abstract}
This paper provides an empirical assessment of the relationship between banking origins and the supply of credit in Ivory Coast. The analysis focuses on 14 banks composed of local banks, African banks and foreign banks outside Africa. The study covers the period from 2000 to 2016. Using the panel data approach, we show that local banks positively influence the supply of credit unlike foreign and African banks. Foreign banks, on the other hand, have a negative influence on the supply of credit in Ivory Coast. In addition, the results highlight the positive impact of growth and market share on the supply of credit to the private sector. On the other hand, the size of banks and the inflation rate are unfavourable to the supply of credit in Ivory Coast. The study suggests that local banks should be strengthened so that they can provide more financing to the Ivorian economy.
\end{abstract}

Keywords: multinational banks, credit supply, model with panel data

\section{Introduction}

The development financing policies of post-independence African countries have been defined within a Keynesian-inspired theoretical framework. In terms of financing activity, interest rates were capped at a very low level in order to encourage investment and economic growth. The State thus controlled the entire financial system and managed the development strategy of its economy. The results of these policies led to low or even negative real interest rates. This practice, described by McKinnon (1973) and Shaw (1973) as financial repression, is said to be the main cause of the poor performance in terms of economic growth in developing countries. According to the authors, financial repression impedes economic development in several ways. First, savings are discouraged because their returns are low. Second, financial intermediaries are not encouraged to allocate savings efficiently. Logically, by adopting a policy of financial liberalization, economic growth is encouraged because higher interest rates will facilitate the mobilization of savings and a more efficient allocation of capital. States should therefore abolish interest rate ceilings, reduce reserve requirements and abolish directed credit programmes. The aim is to "free" the financial markets from any intervention and to let the market determine the distribution of credit. The setting of this rate by market forces is supposed to ensure optimal competition, including the free entry and exit of financial institutions into and out of the banking market. Financial liberalisation should be accompanied by an opening of the banking sector to foreign banks.

Under the aegis of the major international institutions, the majority of sub-Saharan economies undertook financial liberalization programmes from the mid-1980s onwards. In addition to the liberalization of interest rates, many other measures were implemented in Africa as part of financial reforms (bank restructuring, abolition of direct monetary control, strengthening of supervision). However, neo-liberal policies inspired by monetarism have not provided a miracle solution to economic development. Reinhart and Tokatlidis (2003), on sub-Saharan Africa, argue that financial reforms have had very little effect on economies. But in recent years, the banking sector has seen a breakthrough by foreign banks.

According to the annual report of the Central Bank of West African States (BCEAO, 2016), the Ivorian banking sector has experienced sustained growth in recent years, driven by the rise of subsidiaries of West African and Moroccan banking groups. Today, in Ivory Coast, out of 28 financial institutions, nine are Ivorian, and 19 foreigners of several nationalities including Morocco, France, Nigeria, Senegal, Libya, Burkina Faso, Gabon, and Togo. The banking system is dominated by foreign banks, with the three largest (owned by France and Togo) holding nearly 40 percent of banking assets. Other foreign banks, including several Nigerian and Moroccan banks, are smaller. Overall, foreign banks hold about 57 per cent of the assets of the banking system. Most 
foreign banks have healthy balance sheets and strong prudential indicators. In addition, there are a few regional banks, which hold about 19 per cent of assets. At the same time, the banking sector remains underdeveloped. Bank credit to the economy related to GDP went from 14.20 in 1990 to 11.0 in 2000. By 2013, the ratio of private sector credit to GDP is around $18 \%$ and access to financial services is limited (11\% of the population, including microfinance) (IMF, 2013). In 2016, the credit to the economy ratio related to GDP settled at 27.60. According to the profit and loss account of banks, published by the BCEAO, in Ivory Coast, over the period from 2003 to 2006, African banks offer more credit, more than ten points (10\%) ahead of Western banks.

But from 2007 to 2010, the latter outperformed African banks with an increase of more than $20 \%$. Thus the central question of this study can be formulated as follows: to what extent has the origin of the banks influenced the supply of credit in Ivory Coast? The general objective of this study is to analyze the effect of the origin of banks on the supply of credit in Ivory Coast. Specifically, it will examine the effect of domestic banks on the supply of credit in Ivory Coast, on the one hand, and to assess the effect of African-owned banks and other types of foreign banks on the supply of credit. In relation to our objectives, we postulate the following two hypotheses. First, domestic banks positively influence the supply of credit in Ivory Coast. Second, African-owned banks and other types of foreign banks in the country offer more credit than domestic banks.

There is no lack of interest and stake in this study. Indeed, the financing constraints of the economy remain a central issue in sub-Saharan Africa, particularly in the countries of the West African Economic and Monetary Union (WAEMU), where they rhyme with excess bank liquidity. The study contributes to advancing the literature on the link between the origins of banks and the supply of bank credit.

Methodologically, our study is carried out using panel data, with regard to their two dimensions, namely an individual dimension and a time dimension. Because of this characteristic, panel data are particularly suitable for estimating models and testing the theories behind them (Nerlove and Balestra, 1995). The dual dimension of panel data is a decisive advantage over time series and cross-sectional data. This is because this double dimension makes it possible to account simultaneously for the dynamics of behaviour and its possible heterogeneity, which is not possible with time series or cross-section data. The study uses annual data covering the period from 2000 to 2016 and the choice of this period is dictated by data availability. The data used in this study come mainly from a major source, the BCEAO.

This article is organized as follows: Section 2 is devoted to a review of the literature on the relationship between the origins of banks and the supply of bank credit to the private sector. Section 3 presents the methodology of the study. Section 4 presents the data source and the description of the variables. Section 5 will discuss the empirical results, particularly the econometric analysis of the relationship between the origins of banks and the supply of bank credit to the private sector. Section 6 is reserved for the conclusion of the study.

\section{Literature Review}

This section reviews the theoretical and empirical literature on the link between the origin of banks and the supply of bank credit. But well before that, we examine the determinants of the supply of credit.

\subsection{The Literature Review of the Determinants of Credit Supply}

Economic growth and financial deepening would explain the supply of credit provided by foreign banks in Central and Eastern European countries (Burcu, 2008). By studying the determinants of the supply of loans to the private sector in the euro area, Calza and Sousa (2001) indicate that loans are positively correlated with real GDP and negatively correlated with long-term and short-term interest rates. In a recent study, Guo and Stepanyan (2011) indicate that credit growth is associated with the financing of the domestic economy and foreign financing. Strong economic growth leads to an increase in credit, while higher inflation reduces the availability of credit. Based on a sample of 26 Pakistani commercial banks over the period 2001-2010, Hussain and Junaid (2012) found that GDP growth, industrial sector development, bank strength, bank size, exchange rate depreciation, and budget deficit have a significant and positive impact on bank credit supply. Also in Pakistan, Imran and Nishat (2013), over the period 1971 to 2008, using time series based on the econometric approach (ARDL), indicate that external debt, domestic deposits, economic growth, exchange rate and monetary conditions have a significant impact on the supply of bank credit to the private sector in Pakistan, particularly in the long run.

\subsection{The Literature Review of the Relationship Between the Origins of Banks and the Supply of Credit}

At the theoretical level, advocates of bank competition argue that the entry of foreign-owned banks increases market discipline, the efficiency of domestic banks and the supply of credit (Fry, 1995). Foreign banks are expected to bring in new money, new and more efficient technologies and techniques, new skills, and 
competitive pressure on the banking systems in their host markets (Claessens et al., 2001). Thus, greater efficiency in loan allocation should stabilize the banking system, as banks are better able to assess borrowers. The entry of foreign banks into the market reduces relationship-based lending and its negative effects on resource allocation (Bonin \& Imai, 2006; Giannetti \& Ongena, 2005).

The presence of banks with foreign capital may encourage domestic banks to lend more. However, this competitive pressure may lead banks to support high-risk projects as they become less cautious in their lending activities (Demirguç-Kunt \& Detragiache, 1998). In addition, domestic banks would tend to lend less when faced with stronger international competition (Weller, 2001). Moreover, a greater presence of foreign banks could reduce access to credit, especially for SMEs, since these firms rely more on tailored loans. Moreover, foreign banks could show less loyalty to their host countries and withdraw in times of crisis or even in the event of shocks in third countries and in response to global portfolio shifts.

In terms of empirical work, Weller and Scher (2001) examine the determinants of the supply of loans from multinational banks for 72 countries from 1985 to 1998, using data from the Bank for International Settlements and the International Monetary Fund. We find that MNC loans are larger where MNC deposits are larger. Similarly, they are larger with the number of years of experience in the country and where there are greater opportunities for profit, where current account deficits are larger, where inflows of FDI are larger, and where the currency is more undervalued in real terms. In the case of China, in a sample of 31 banks from 2002 to 2009 , Huang and Zeng (2011) find that the entry of foreign banks into the domestic market has not increased supply, but has significantly improved the structure of domestic banks' activities.

For their part, Fungacova et al. (2013) analyse the influence of bank ownership on the supply of credit in the context of the recent financial crisis in Russia. Their results indicate that bank ownership affects the supply of credit during the financial crisis and that the crisis led to an overall decrease in the supply of credit. Their findings suggest bank ownership affected credit supply during the financial crisis and that the crisis led to an overall decrease in the credit supply. Relative to domestic private banks foreign-owned banks reduced their credit supply more and state-controlled banks less. This supports the hypothesis that foreign banks have a "lack of loyalty" to domestic actors during a crisis, as well as the view that an objective function of state-controlled banks leads them to support the economy during economic downturns.

These results support the idea that foreign banks "lack loyalty" to domestic players in times of crisis, and that a state-controlled bank is willing to support the economy in times of economic downturn. Clarke et al. (2003) find that borrowers in countries where there is a stronger presence of foreign banks report lower barriers to financing and are more likely to have access to bank credit. They are interested in offering credit because they also make more profit than locally owned banks (Honohan \& Beck, 2007).

\section{Model and Econometric Methodology}

In this section, we present, first, the model specification and second, the methodology of the study.

\subsection{The Empirical Model}

The model to be estimated in this paper can be specified as follows::

$$
C R E D_{i t}=\theta_{i t}+\theta_{1} F I_{i t}+\theta_{2} \operatorname{SIZE}_{i t}+\theta_{3} \text { MSHARE }_{i t}+\theta_{4} \text { ZSCORE }_{i t}+\theta_{5} I N F_{i t}+\theta_{6} G D P_{i t}+\mu_{i t}
$$

Where CRED is the bank credit granted to the private sector in relation to total assets. FSI represents the dummy variables that capture the different origins of banks. In fact, this variable takes the value 1 for African-owned banks (non-domestic) and the value 0 for other banks (origin 1). Then, it takes the values 1 for domestic banks and 0 for other banks (origin 2). Finally, it takes the value 1 for other types of banks and the value 0 otherwise. SIZE is the size of the banks, it is obtained from the logarithm of the active total. For Bédué and Lévy (1997), the size of an institution is like a source of information for the lender. MSHARE is the market share of each bank. It is given by credit granted by the bank on the total credit issued by banks in the country. To defend their market share, banks may extend credit to borrowers whose projects are risky (Darity \& Horn, 1988). ZSCORE measures a bank's solvency. It provides a level of risk for the bank. Indeed, the Zscore is obtained by summing the net banking profit to asset size (ROA), and the equity on the balance sheet, all divided by the standard deviation of the ROA. INF, is the inflation rate, which is measured here by the growth rate of the consumer price index (CPI). GDP is the growth rate of gross domestic product (GDP), an economic indicator that measures a country's domestic economic output.

\subsection{The Panel Estimation}

We conduct this study using panel data. The panel is a database in which two dimensions are present, namely an 
individual dimension and a time dimension. The dual dimension offered by panel data is a major advantage, as it allows controlling for heterogeneity between individuals (Nerlove and Balestra, 1995). Therefore, the model (1) can be again specified as follows:

$$
\operatorname{CRED}_{i t}=\alpha_{i t}+\beta_{1} F S I_{i t}+\beta_{2} \operatorname{SIZE}_{i t}+\beta_{3} \text { MSHARE }_{i t}+\beta_{4} Z_{\text {SCORE }}+\beta_{5} I N F_{i t}+\beta_{6} G D P_{i t}+\mu_{i t}
$$

With $i=1, \ldots, T, t=1, \ldots, 22$; x1 it, the value of the $j$-ième variable for I-ième unit to the period $\mathrm{t}, j=1, \ldots, 7$. $\mathrm{K}$ is the number of explanatory variables model and $\alpha \mathrm{it}, \beta \mathrm{i}$, the coefficients of exogenous variables for the individual i. finally, $\mu$ it is the term errors for the individual $i$ on the date $t$.

This model assumes that each individual has a specific behavior, which is differentiated from one period to another. Initially devoid of any economic interest, the model becomes interesting as soon as it imposes identification restrictions, which correspond to the different hypotheses that one wishes to test. In the economic literature, three hypotheses that we present in our study are most often retained.

First the homogeneous model. This type of model assumes the presence of uniform behavior between individuals. Estimating model returns to be applied simply the ordinary least squares (OLS) on all the data set end-to-end without worrying their specific nature or that of hazard and. in this model, all coefficients are identical. In this case we can write:

It follows that our model is given by:

$$
H 1:\left\{\begin{array}{c}
\alpha_{i t}=\alpha \\
\beta_{k i t}=\beta_{k}
\end{array} \text { et } H 2: \mu_{i t}=\operatorname{iiN}\left(0, \sigma^{2}\right)\right.
$$

$$
C R E D_{i t}=\alpha+\beta_{1} F I_{i t}+\beta_{2} \operatorname{SIZE}_{i t}+\beta_{3} \text { MSHARE }_{i t}+\beta_{4} Z S C O R E_{i t}+\beta_{5} I N F_{i t}+\beta_{6} G D P_{i t}+\mu_{i t}
$$

If one assumes the existence of difference of behavior between individuals, then this model is no more suitable.

Individual Effect Model and Random Effect Model. In this case, we distinguish between the fixed-effect model where the individual effect is constant over time and the random-effect model where the constant term is a random variable.

\section{- Fixed effects}

The fixed-effects model takes into account the heterogeneity of the behaviours of the individuals that make up the sample by considering that the equations that govern the relationships $\mathrm{X} \rightarrow \mathrm{Y}$ differ from one individual to another by a constant. The method of estimating the parameters depends on the structure of the error terms. If the errors are homoscedastic, not autocorrelated in the time dimension and in the individual dimension, the Least Square Dummy Method (LSDV) is used on the indicator variables (LSDV = Least Square Dummy Variable) or on the Within estimators.

On the other hand, if the errors are heteroskedastic and/or autocorrelated in the time dimension but independent in the individual dimension, the Generalized Least Squares Method (GCM) is used on the indicator variables (LSDV) or on the Within estimators. In the case where systematic effects are represented by the original intercepts $\alpha_{i}$ for each individual the hypotheses can be written as follows:

The equation is also given by:

$$
H 1:\left\{\begin{array}{c}
\alpha_{i t}=\alpha_{i} \\
\beta_{k i t}=\beta_{k}
\end{array} \text { et } H 2: \mu_{i t}=i i N\left(0, \sigma^{2}\right)\right.
$$

$$
\operatorname{CRED}_{i t}=\alpha_{i}+\beta_{1} \text { SSI }_{i t}+\beta_{2} \operatorname{SIZE}_{i t}+\beta_{3} \text { MSHARE }_{i t}+\beta_{4} \text { ZSCORE }_{i t}+\beta_{5} I N F_{i t}+\beta_{6} G D P_{i t}+\mu_{i t}
$$

In the absence of structural specificity of the endogenous variable, which differs from one individual to another, it is possible to retain another hypothesis: that of the random effect.

\section{- Random effects}

The random-effect model assumes that the relationship between the variable to be explained and the explanatory variables is no longer fixed but random. The individual effect (constant) is no longer fixed but random. This model can be written as follows:

The equation is also given by:

$$
H 1:\left\{\begin{array}{c}
\alpha_{i t}=\alpha \\
\beta_{k i t}=\beta_{k}
\end{array} \text { et } H 2: \mu_{i t}=\alpha_{i}+\varepsilon_{i t}\right.
$$

$$
\operatorname{CRED}_{i t}=\alpha+\beta_{1} F S I_{i t}+\beta_{2} \operatorname{SIZE}_{i t}+\beta_{3} M_{\text {SHARE }}+\beta_{4} Z S C O R E_{i t}+\beta_{5} I N F_{i t}+\beta_{6} G D P_{i t}+\mu_{i t}
$$

To choose between the two models, the Hausman (1978) test is applied, which is a specification test to determine whether the coefficients of the two estimates (fixed and random) are statistically different. The statistic of this 
test is a Chi-square with $\mathrm{k}$ degrees of freedom. If the probability of the test is less than 5\%, then the estimators within are unbiased. Otherwise, we will use the GCM estimators or the random-effect model.

\subsection{Stationarity and Co-Integration Test}

The robustness of the results depend on the compliance with the characteristics stochastic series. To do this, should be applied the stationarity tests and if any, co-integration test. There is stationarity of the variables if the characteristics (expectancy and variance) are not modified over time. It is difficult, if not impossible, to clearly identify the stochastic characteristics of a series if it is not stationary. In panel, the most widely used test to analyze the stationarity of the variables is that of Im-Pesaran and Shin (2003) (when the intertemporal dimension is weak) and Levin Lin and Chu (2002).

\section{Data and Descriptive Statistics}

In this section, we present the data source and descriptive statistics for the variables in the model.

\subsection{Data Sources}

The empirical study is based on a panel of 14 banks out of 28 present in Ivory Coast over the period (2000-2016). The data used in this study come mainly from the BCEAO, the banks' profit and loss account. The choice of this study period gives credibility to the study conducted in the country. According to the latest BCEAO reports, in the WAEMU zone, the Ivorian banking sector is the largest in the country. In 2018, there were 28 banks and 2 financial institutions. The first in terms of market share is General society of Ivory Coast. It is followed by Ecobank, SIB and BICICI.

\subsection{Descriptive Statistics}

Descriptive statistics for all variables are reported in Table 1. The matrix of Pearson correlation coefficients is summarized in Table 2. Examination of Table 1 provides information on the dynamics of credit supply in Ivory Coast. It emerges that the credit distributed by banks to businesses and individuals in Ivory Coast represents $80.13 \%$ of their assets with a maximum value of $90.95 \%$.

The banks' market share varied widely, between -9.47 and 95.73 , reflecting the relative competition in the sector. Credit risk averaged $3.15 \%$. The inflation rate is on average low in the country, at $2.590 \%$. Based on a trade-off between inflation and activity, it follows that the cost of disinflation has weighed on activity, which is $3.045^{\circ} \%$ on average. Table 2 shows a low correlation between the explanatory variables. Of all these variables, the growth rate (GDP) and the inflation rate (INF) pair has the highest correlation coefficient (-0.5183) but well below 0.8 . The market share and credit granted pair also has an average correlation of 0.4313 . We still decide to include all the variables in our model because of their theoretical interest.

Table 1. Descriptive analysis of variables

\begin{tabular}{cccccc}
\hline Variables & Obs & Mean & Std.Dev. & Min & Max \\
\hline CRED & 232 & 80.127 & 146.9864 & -52.294 & 90.953 \\
MSHARE & 232 & 7.608 & 9.504106 & -9.476 & 95.735 \\
SIZE & 232 & 5.102 & 0.5376633 & 3.672 & 6.144 \\
GDP & 238 & 3.045 & 4.533 & -4.387 & 10.706 \\
INF & 238 & 2.590 & 1.522877 & 0.453 & 6.308 \\
ZSCORE & 232 & 3.151 & 3.634 & -1.373 & 22.338 \\
\hline
\end{tabular}

Source: Author based on BCEAO data (2017).

Table 2. Correlation matrix

\begin{tabular}{ccccccc}
\hline & CRED & SIZE & MSHARE & ZSCORE & INF & GDP \\
CRED & 1.0000 & & & & & \\
SIZE & $-0.2050^{*}$ & 1.0000 & & & & \\
MSHARE & $0.4313^{*}$ & $0.4390^{*}$ & 1.0000 & & & \\
ZSCORE & $0.2350^{*}$ & $-0.1723^{*}$ & -0.0327 & 1.0000 & & \\
INF & 0.0309 & -0.0960 & $0.2190^{*}$ & $-0 / 0701$ & 1.0000 & \\
GDP & -0.0494 & $0.2414^{*}$ & -0.1254 & 0.0929 & $-0.5183^{*}$ & 1.0000 \\
\hline
\end{tabular}

Note. $*$ significativité au seuil de $5 \%$.

Source: Author based on BCEAO data (2017). 


\section{Empirical Results}

The empirical analysis takes the following approach. First, we apply unit root tests to the series to study the stationarity of the variables. Second, we estimate the long-term coefficients.

\subsection{Unit Root and Cointegration Test Results}

The order of integration of the variables is tested according to the Im, Peseran and Shin tests (IPS, 2003) and the Fisher-type test. The IPS test corrects for deficiencies related to the heterogeneity of the individuals in the panel, i.e. the constants specific to each individual. This reflects our data with the different origins and the credit supply policies specific to each bank. As for the Fisher- Type test, its choice resides in the fact that it tests the stationarity of the variables which present constant terms and which contain null values. The results reported in Table 3 indicate that all variables are level-stationary.

Table 3. Stationarity test results

\begin{tabular}{|c|c|c|c|c|c|c|c|}
\hline \multirow{3}{*}{ Variables } & \multicolumn{5}{|c|}{ IPS } & \multirow{2}{*}{\multicolumn{2}{|c|}{$\begin{array}{c}\text { ADF-Fisher } \\
\text { Niv }\end{array}$}} \\
\hline & \multicolumn{2}{|c|}{ Niv } & \multicolumn{2}{|c|}{ Diff (1) } & \multirow[b]{2}{*}{ Décision } & & \\
\hline & Stat & P-values & Stat & P-values & & Stat & P-values \\
\hline CRED & $-4.028 * * *$ & 0.000 & $-7.391 * * *$ & 0.000 & Stationary & $73.041 * * *$ & 0.000 \\
\hline SIZE & $-3.711 * * *$ & 0.000 & $-7.320 * * *$ & 0.000 & Stationary & $75.622 * * *$ & 0.000 \\
\hline MSHARE & $-2.203^{* * *}$ & 0.013 & $-7.190 * * *$ & 0.000 & Stationary & $34.921 * * *$ & 0.027 \\
\hline ZSCORE & $-4.277 * * *$ & 0.000 & $-8.127 * * *$ & 0.000 & Stationary & $60.503^{* * *}$ & 0.000 \\
\hline GDP & $-6.914 * * *$ & 0.000 & $-9.087 * * *$ & 0.000 & Stationary & $106.154^{* * *}$ & 0.000 \\
\hline INF & $-9.666^{* * * *}$ & 0.000 & $-9.864 * * *$ & 0.000 & Stationary & $373.648^{* * *}$ & 0.000 \\
\hline
\end{tabular}

Source: Author based on BCEAO data (2017).

NOTE: Values marked with stars $(* * *)$ indicate significance at the $1 \%$ threshold.

\subsection{Results of Individual Fixed-Effects Model Estimation}

When choosing between the common-effect or fixed-effect model, the first thing to check is the homogeneous or heterogeneous specification of the data generating process. Econometrically, this is equivalent to testing the equality of the coefficients of the model studied in the individual dimension. Table 4 shows that the evidence for including the individual effects or specificity of each bank is well confirmed. Indeed, the p-value associated with the test statistic is less than 5\% ( $F$ test that all ui=0: $F(13,213)=4.47$ Prob $>F=0.000$ ). We cannot reject the null hypothesis of the absence of specific effects at the $5 \%$ threshold. In this case, the model to be estimated is qualified as a heterogeneous panel.

Table 4. Testing individual effects

\begin{tabular}{lccc}
\hline Variables & Coefficients & Statistique de student & P-value \\
\hline SIZE & -69.641 & 49.776 & 0.163 \\
MSHARE & -12.567 & 3.796 & 0.001 \\
ZSCORE & 7.540 & 3.717 & 0.044 \\
INF & 10.440 & 6.832 & 0.128 \\
GDP & 1.548 & 2.749 & 0.575 \\
Constante & 473.555 & 243.362 & 0.053 \\
\hline R-squared $:$ within $=\mathbf{0 . 2 2 7 0}$ & & & \\
Overall $=\mathbf{0 . 0 5 4 5}$ & & & \\
F test that all $\mathbf{u} \mathbf{i}=\mathbf{0}: \mathbf{F}(\mathbf{1 3}, \mathbf{2 1 3})=\mathbf{4 . 4 7}$ & $\mathbf{P r o b}>\mathbf{F}=\mathbf{0 . 0 0 0 0}$ & \\
\hline
\end{tabular}

Source: Author based on BCEAO data (2017).

The Hausman test allows to discriminate between the fixed effects and random effects model. Table 5 indicates that the fixed effects are efficient, the p-value is Prob $>$ chi $2=0.0630$. We can now perform the validation tests. The heteroskedasticity test applied here is the Breush-Pagan / Cook-Weisberg test. The results (Wald chi2(7) = 143.19 Prob > chi2 $=0.0000$ ) indicate the presence of heteroskedasticity. Indeed, the p-value is below the $5 \%$ threshold, which does not allow us to reject the null hypothesis. In this case, the heteroskedasticity should be corrected with the GCM method in order for our inference to be valid. After testing the heteroskedasticity of the intra-individual 
errors, we proceed to check the correlation and autocorrelation of the errors. For the wooldridge test for autocorrelation in panel data, the result indicates a first-order first-order correlation (Prob $>F=0.0000$ ). This p-value is below the 5\% threshold. This confirms the use of GCMs. After carrying out all these tests, it emerges that the model to be used for the analysis and interpretation of the coefficients is the GCM model with error and heteroskedasticity correction. The estimation results are reported in Table 6. Our variable of interest, which is the origin of banks (OIB), captures three modalities, and thus requires three estimates to avoid multicollinearity among the exogenous variables. Note that Origin 1 and Origin 3 represent African, non-domestic and foreign non-African banks, respectively. Origin 2 represents domestic banks. At the origin level, the results indicate that domestic banks have a positive effect on the supply of credit in Ivory Coast. On the other hand, African (non-domestic) banks and other foreign banks have a negative effect on the supply of credit in the country. Our results agree with those of Weill (2006) on foreign ownership and technical efficiency of banks.

In terms of size, it is significant but has a negative impact on the supply of credit. Indeed, size does not perfectly determine a bank's willingness or ability to grant credit. This negative sign could be explained by banks' preference for the financial market and the purchase of government securities, which are less risky.

The market share (Mshare/credit) and the Zscore have a positive and significant influence on the credit offer. Indeed, the Zscore is positively correlated to the bank's solvency. Thus, when the Zscore is high, the supply of credit is also high and the opposite is true when it decreases. It should also be noted that the supply of credit is proportional to the banks' market share. Even if the bank is able to create money from a simple writing game, its market share is a guarantee of credibility and confidence for borrowers.

Table 5. Results of Hausman test

\begin{tabular}{|c|c|c|c|c|}
\hline \multirow[t]{2}{*}{ Exogenous Variables } & \multicolumn{2}{|c|}{ Coefficients } & \multirow[t]{2}{*}{ Difference (B-b) } & \multirow[t]{2}{*}{ Std. Deviation } \\
\hline & Random (b) & Fixed (B) & & \\
\hline SIZE & $-152,153$ & $-221,739$ & $-69,586$ & 23,700 \\
\hline MSHARE & 11,328 & 10,970 & $-0,358$ & 0,2183 \\
\hline ZSCORE & 8,786 & 5,560 & $-3,226$ & 1,657 \\
\hline INF & $-11,313$ & $-10,063$ & 1,250 & 0 \\
\hline GDP & 3,055 & 5,649 & 2,593 & 0,871 \\
\hline \multicolumn{5}{|c|}{ Chi2 $(5)=(b-B)^{\prime}\left[\left(V_{-} b-V \_B\right)^{\wedge}(-1)\right](b-B)=10.47$} \\
\hline \multicolumn{5}{|c|}{ Prob $>$ chi $2=0.0630$} \\
\hline
\end{tabular}

Source: Author based on BCEAO data (2017).

Table 6. Result of the estimates (endogenous variable: the credit/asset ratio)

\begin{tabular}{|c|c|c|c|c|c|c|}
\hline \multirow{3}{*}{$\begin{array}{c}\text { Variables } \\
\text { ORIGINE } 1 \\
\text { ORIGINE } 2\end{array}$} & \multicolumn{2}{|c|}{ Estimation 1} & \multicolumn{2}{|c|}{ Estimation 2} & \multicolumn{2}{|c|}{ Estimation 3} \\
\hline & $-20.879 * *$ & $(0.024)$ & \multicolumn{2}{|c|}{---- } & \multicolumn{2}{|c|}{----- } \\
\hline & \multicolumn{2}{|c|}{---- } & $39.612 * * *$ & $(0.001)$ & --- & \\
\hline ORIGINE 3 & --- & & --- & & $-36.731 * * *$ & $(0.012)$ \\
\hline SIZE & $-94.067 * * *$ & $(0.000)$ & $-105.068^{* * *}$ & $(0.000)$ & $-92.583 * * *$ & $(0.000)$ \\
\hline MSHARE & $7.633 * * *$ & $(0.000)$ & $8.050^{* * *}$ & $(0.000)$ & $8.515^{* * *}$ & $(0.000)$ \\
\hline ZSCORE & $8.372 * * *$ & $(0.000)$ & $7.715^{* * * *}$ & $(0.000)$ & $8.949 * * *$ & $(0.000)$ \\
\hline GDP & 1.047 & $(0.217)$ & 1.134 & $(0.173)$ & $0.333^{*}$ & $(0.070)$ \\
\hline INF & $-3.550^{*}$ & $(0.060)$ & $-3.448 * *$ & $(0.044)$ & $-3.652 * *$ & $(0.035)$ \\
\hline Cons & $498.102 * * *$ & $(0.000)$ & $534.593 * * *$ & $(0.000)$ & $482.226 * * *$ & $(0.000)$ \\
\hline
\end{tabular}

Note. Stars *, ** and *** indicate respectively the significance at the $10 \%, 5 \%$ and $1 \%$ threshold.

Source: Author based on BCEAO data (2017).

The results show that inflation negatively affects the supply of credit. This result is contrary to Huang and Zen (2011), who find that the increase in the inflation rate induces banks to make more loans. Their problem may be that they have overlooked the cost to the borrower. In fact, rising inflation leads to high interest rates, which increases the cost of credit, discourages firms from borrowing, and thus reduces the availability of credit. Our results confirm those of Jiménez et al. (2017), for whom less favourable economic conditions significantly reduce lending.

As for the growth rate, it is favourable to the supply of credit from non-domestic and non-African banks. A 
positive growth rate is synonymous with increased business production and consumption. In this case, the prospects for loan repayment are good. This is what encourages foreign banks to grant more loans.

\section{Concluding Remarks}

In this study, our objective was to analyze the effect of bank origins on the loan supply of 14 banks in Ivory Coast over the period 2000 to 2016 . To do so, we estimated a panel data model. From the results, three major lessons can be drawn. The first is that foreign banks have a negative influence on the supply of credit in Ivory Coast. It is domestic banks that have a positive influence on the supply of credit to the private sector. The monetary authorities should encourage the creation of local or national banks. The financing of private investment will be facilitated with local banks and not foreign banks. Because of the irreversibility of investment, foreign banks are sometimes reluctant to support the activity. Moreover, the results indicate that they are in favour of distributing credit according to the economic health of the country. The inflation rate is also a factor that discourages the supply of credit. Inflation causes banks to raise interest rates, which increases the debt burden, thereby discouraging potential borrowers.

The second lesson is that increasing the size of banks is not conducive to the supply of bank credit. In general, the increase in bank assets is achieved by subscribing to securities issued by governments. These securities, which are supposed to be safer than loans, crowd out potential borrowers from the credit market. Monetary authorities could cap the amount of government securities held so as not to discourage support for activity. The third lesson is that the larger a bank's market share, the more it is able to make bank loans. Banking concentration is therefore desirable for the supply of bank credit in Ivory Coast.

\section{References}

Aydin, B. (2008). Banking Structure and Credit Growth in Central and Eastern European Countries. IMF Working Papers, WP/08/215, International Monetary Fund. https://doi.org/10.5089/9781451870732.001

Bédué, A., \& Lévy, N. (1997). Relation banque-entreprise et coût du crédit. Revue d'Economie Financière, 39, 179-200. https://doi.org/10.3406/ecofi.1997.2297

Bonin, J., \& Imai, M. (2006). Soft Related Lending: A Tale of Two Korean Banks. Journal of Banking and Finance, 31(6), 1713-1729. https://doi.org/10.1016/j.jbankfin.2006.11.007

Calza, A. C., \& Sousa, J. (2001). Modelling the demand for loans to the private sector in the Euro area. Working paper $\quad n^{\circ} 55$, European Central Bank. Retrieved from https://www.ecb.europa.eu//pub/pdf/scpwps/ecbwp055.pdf

Christian, E., Weller, C. E., \& Scher, M. (2001). Multinational Bank Credit in Less Industrialized Economies. Journal of International Business Studies, 32(4), 833-851. https://doi.org/10.1057/palgrave.jibs.8490999

Claessens, S., Demirguc-Kunt, A., \& Huizinga, H. (2001). How Does Foreign Bank Entry Affect Domestic Banking Markets? Journal of Banking and Finance, 25(5), 891-911. https://doi.org/10.1016/S0378-4266(00)00102-3

Clarke, G., Cull, R., Martinez, P. M. S., \& Sanchez, S. M. (2003). Foreign Bank Entry: Experience, Implications for Developing Countries, and Agenda for Further Research. The World Bank Research Observer, 18(1), 25-59. https://doi.org/10.1093/wbro/lkg002

Darity, W., \& Horn, B. L. (1988). The Loan Pushers: The Role of Commercial Banks in the International Debt Crisis. Cambridge, MA: Harper and Row, Ballinger.

Demirgüc-Kunt, A., \& Detragiache, E. (1998). Determinants of banking crises in developed and developing countries. IMF Staff Papers, 45(1), 81-109. https://doi.org/10.2307/3867330

Demirgüç-Kunt, A., \& Detragiache, E. (1998). Financial Liberalization and Financial Fragility. IMF Working Paper, 1998(83), 1-36. https://doi.org/10.5089/9781451850512.001

Fry, M. (1995). Money, Interest, and Banking in Economic Development (2nd ed.). Baltimore MD: Johns Hopkins University Press.

Fungacova, Z., Herrala, R., \& Weill, L. (2013). The Influence of Bank Ownership on Credit Supply: Evidence from the Recent Financial Crisis. Emerging Markets Review, 15, 136-147. https://doi.org/10.1016/j.ememar.2013.02.002

Giannetti, M., \& Ongena, S. (2005). Financial Integration and Entrepreneurial Activity: Evidence from Foreign Bank Entry in Emerging Markets. European Central Bank Working Paper 498. Retrieved from https://www.ecb.europa.eu/pub/pdf/scpwps/ecbwp498.pdf 
Guo, K., \& Stepanyan, V. (2011). Determinants of Bank Credit in Emerging Market Economies. IMF Working Paper. WP/1 1/51. https://doi.org/10.5089/9781455218035.001

Honohan, P., \& Beck, T. (2007). Making Finance Work for Africa. World Bank, Washington. https://doi.org/10.1596/978-0-8213-6909-8

Huang, X., \& Zeng, Y. (2011). The Impacts of Foreign Bank Entry on Credit Scale and Business Structure of Chinese Commercial Banks. Modern Economy, 2(5), 814-822. https://doi.org/10.4236/me.2011.25090.

Hussain, I., \& Junaid, N. (2012). Credit Growth drivers: A case of Commercial banks of Pakistan. ResearchGate. Retrieved from https://www.researchgate.net/publication/236002456

Im K. S., Pesaran, M. H., \& Shin, Y. (2003). Testing for Unit Roots in Heterogeneous Panels. Journal of Econometrics, 115(1), 53-74. https://doi.org/10.1016/S0304-4076(03)00092-7.

IMF. (2013). Côte d'Ivoire: 2013 Article IV Consultation and Fourth Review Under the Extended Credit Facility Arrangement. IMF Report No. 13/367. Fonds monetaire international, Washington, DC. https://doi.org/10.5089/9781484313213.002

Imran, K., \& Nishat, M. (2013). Determinants of bank credit in Pakistan: A supply side approach. Economic Modelling, 35(C), 384-390. https://doi.org/10.1016/j.econmod.2013.07.022

Jiménez G., Ongena, S., Peydró, J.-L., \& Saurina, J. (2017). Macroprudential policy, countercyclical bank capital buffers and credit supply: Evidence from the Spanish dynamic provisioning experiments. Journal of Political Economy, 125 (6), 2126 - 2177. https://doi.org/10.1086/694289

Levin, A., Lin, C. F., \& Chu, C. S. J. (2002). Unit Root Tests in Panel Data: Asymptotic and Finite Sample Properties. Journal of Econometrics, 108(1), 1-24. https://doi.org/10.1016/S0304-4076(01)00098-7

McKinnon, R. I. (1973). Money and Capital in Economic Development. Washington DC: Brookings Instiution

Nerlove, M., \& Balestra, P. (1995). Formulation end estimation of econometric models for panel data. In L. Matyas, \& P. Sevestre (Eds.), the econometrics of panel data: A handbook of the theory with applications (pp. 3-22). Dordrecht: Kluver Academic Publishers. https://doi.org/10.1007/978-94-009-0137-7_1

Reinhart, C., \& Tokatlidis, I. (2003), Financial liberalization: The African experience. Journal of African Economies, 12(1), 53-88. https://doi.org/10.1093/jae/12.suppl_2.ii53

Shaw, E. S. (1973). Financial Deepening in Economic Growth. New York: Oxford University Press.

Weill, L. (2006). Propriété etrangère et efficience technique des banques dans les pays en transition. Revue économique, 57(5), 1093-1108. https://doi.org/10.3917/reco.575.1093

Weller, C. E. (2001). The supply of credit by multinational Banks in developing and transition economie: Determinants and Effect. DESA Discussion Paper No. 16. Retrieved from https://pdfs.semanticscholar.org/b8b2/b9a56b7e0828597a7d28efa9449d23a79beb.pdf

\section{Copyrights}

Copyright for this article is retained by the author(s), with first publication rights granted to the journal.

This is an open-access article distributed under the terms and conditions of the Creative Commons Attribution license (http://creativecommons.org/licenses/by/4.0/). 